\title{
Universiteit
}

Leiden

The Netherlands

\section{Who should be admitted? Conjoint analysis of South Korean attitudes toward immigrants \\ Denney, S.; Green, C.K.}

\section{Citation}

Denney, S., \& Green, C. K. (2020). Who should be admitted?:

Conjoint analysis of South Korean attitudes toward immigrants.

Ethnicities, 21(1), 120-145. doi:10.1177/1468796820916609

Version: $\quad$ Publisher's Version

License: $\quad$ Licensed under Article 25fa Copyright Act/Law (Amendment Taverne)

Downloaded from: $\quad$ https://hdl.handle.net/1887/3200878

Note: To cite this publication please use the final published version (if applicable). 
Who should be admitted? Conjoint analysis of South Korean attitudes toward immigrants
Ethnicities

202I, Vol. 2I(I) I20-145

(C) The Author(s) 2020

Article reuse guidelines: sagepub.com/journals-permissions DOI: 10.1 I77/|4687968209|6609

journals.sagepub.com/home/etn

@AGE

\title{
Steven Denney (D)
}

Munk School of Global Affairs and Public Policy, University of

Toronto, Canada

\section{Christopher Green}

Institute for Area Studies, Leiden University, the

Netherlands

\begin{abstract}
South Korea is slowly but steadily becoming a country of immigrants. In 1998, there were barely 300,000 foreign residents in South Korea. As of 2018, there were more than 2.3 million. The immigrant population has yet to reach $5 \%$ of the total population, but it is predicted to rise significantly in the years to come. Despite the increase in newcomers, it is not well understood who native South Koreans prefer as immigrants and why. Are immigrant attitudes motivated by co-ethnic solidarity, or are they primarily based on economic and sociotropic concerns? To isolate attitudes on these crucial questions, this research uses a conjoint experiment that simultaneously tests the influence of seven immigrant attributes in generating support for admission. Our results show that broad sociotropic concerns largely drive attitudes towards immigrants in South Korea, but an immigrant's origin also matters. Prospective newcomers from culturally similar and higher-status countries who can speak Korean and have clear plans to work are most preferred. The research findings will be relevant to the comparative study of immigration attitudes, as well as to researchers interested in the specifics of the South Korean case.
\end{abstract}

\section{Corresponding author:}

Steven Denney, Munk School of Global Affairs and Public Policy, University of Toronto, I Devonshire PI, Toronto, ON M5S 3K7, Canada.

Email: steven.denney@utoronto.ca 


\section{Keywords}

Korea, immigration, experiments, national identity, political culture

South Korea is becoming an increasingly diverse place. A country with only 300,000 foreign residents in 1998 had, in 2018, more than seven times that number: 2.36 million and rising. ${ }^{1}$ Though still only constituting some $3 \%$ of the total population - far fewer than 2017 figures for Germany (15\%) and the United States and UK (13\%) - the trend of immigration into Korea is unmistakably upwards. ${ }^{2}$ Yet, despite noteworthy growth in overall immigrant numbers, it remains uncertain whom South Koreans actually prefer as immigrants. Given a post-colonial history of ethnic nationalism, it is often assumed that, when given the chance, South Koreans would select fellow ethnic Koreans from around the world as their preferred immigrants. But is this the case? In the 21 st century, are native Korean attitudes to immigration motivated primarily by co-ethnic solidarity? Or, in keeping with research from other locales, are sociotropic evaluations more salient than ethnicity when it comes to making decisions about immigration? In this paper, we investigate these questions.

The existing literature on South Korean attitudes to immigration is inconclusive. Cross-nationally, South Koreans profess a relatively open and accepting view of immigrants (Boyon, 2018; Poushter et al., 2019). However, an exclusionary ethnic dimension remains salient (Seol and Skrentny, 2009; Yoon, 2016). $\mathrm{Ha}$ et al. (2016) establish a preference for defector-migrants from North Korea as immigrants, while Kong et al. (2010) conclude that South Korean immigration and immigrant policies are driven, to a degree, by ethnicity.

Yet, Seol and Skrentny (2009), Choi (2016), and Oh and Oh (2016) also find a hierarchy of socio-economic development among those countries that send coethnics to South Korea, implying that socio-economic motivations are at play, and $\mathrm{Ha}$ et al. (2016) see no significant difference in views of co-ethnics from China and non-Korean ethnic migrants from Indonesia. Hundt (2016) asserts that generational differences and education levels are key drivers of opinion, with younger, better educated people more open to immigration than older and less well-educated cohorts, without much regard for ethnicity. Kong et al. (2010) find that the needs of the labor market and the urgency of correcting rural gender imbalances are as important as ethnicity. Both Kong et al. (2010) and Lim (2009) anticipate that South Korea is likely to evolve into a country of immigrants irrespective of ostensible concerns over the shifting ethnic landscape of the country.

This paper uses an experimental research design to resolve some of the uncertainty. In contrast to existing studies, which rely mainly on observational research 
designs, our choice-based conjoint experiment permits simultaneous testing of the influences of multiple variables and competing hypotheses about support for immigration in South Korea, and from there to isolate drivers of immigration attitudes. Explained in greater detail later, the choice-based conjoint experiment explores the effects of seven immigrant attributes on the probability of being accepted for entry into South Korea. These are the prospective immigrants' reason for application, country of origin, Korean language capacity, profession, employment plans, and ethnicity. The design provides respondents a substantial amount of information about potential immigrants and permits the researcher to disaggregate theoretically relevant immigrant attributes, reducing, at the same time, the danger of social desirability biasing the responses.

The results of this choice-based conjoint show that broad 'sociotropic' concerns largely drive attitudes towards immigrants in South Korea. Respondents select primarily on grounds of language capacity and employment plans, and not on grounds of ethnicity. Prospective newcomers who can speak Korean and have clear plans to work are most preferred. These findings are largely in line with findings from similar empirical strategies used in Canada (Donnelley, 2017) and the United States (Hainmueller and Hopkins, 2014).

However, the Korean case also has some distinguishing features. South Koreans show noteworthy origins-based discrimination, putting them more in line with some Western European countries whose citizens show greater cultural anxiety towards those hailing from culturally dissimilar places than is generally the case in North America (Johnson and Rodger, 2015; Sobolewska et al., 2017). There are also some co-ethnic and gender effects, but these are modest when compared to sociotropic and origins-based concerns. The experimental method we have employed serves to make the findings all the more relevant to the comparative study of immigration attitudes, as well as to researchers interested in the specifics of the South Korean case.

\section{Overview of immigration in South Korea}

The major sources of migration into South Korea in the last two decades have been threefold. Migrant workers are the first and the largest group, followed by marriage migrants, and then, a distant third, North Korean defector-migrants (Kim, 2004, 2009; Park, 1994). ${ }^{3}$ As of 2018, South Korea was home to approximately 900,000 'employed foreign residents' (migrant workers), 125,000 people on F-6 visas, the category for those married to natives, and more than 32,000 former residents of North Korea.

Rapidly increasing immigration to South Korea is an outcome of the country's rising affluence and falling birthrate. The country's GDP per capita rose from US $\$ 11,900$ in 2000 to almost US\$30,000 in 2017, while the income gap between Korea and most Asian states widened. ${ }^{4}$ Meanwhile, a dramatic economic downturn in the late 1990s resulted in large numbers of Korean women migrating internally to find places in the educated urban workforce, undercutting existing patriarchal norms of 
family and promoting late marriage and delayed parenthood. This has, in turn, exacerbated the consequences of a persistently low birthrate - just 358,000 babies were born in South Korea in 2017, far below the replacement rate (Statistics Korea, 2018). This has incited economic and social difficulties in rural communities. These imbalances pull in mostly male laborers and female marriage migrants, most notably from China, Vietnam, and the other countries of Southeast Asia.

In the light of challenging circumstances, consecutive South Korean governments have eased processes of entry and settlement for migrant labor, as Draudt (2019), Hundt (2016), and Kim (2014) all note. Seoul's turn towards a relatively pro-immigration position began with the 1991 Foreign Trainees Program for Overseas Firms, which covered six countries. This was followed by the Foreign Industrial Trainees Program in 1993, which expanded Seoul's reach to 15. The Employment Permits System (EPS) was introduced in 2003, partially to combat the problem of high dropout rates from previous programs leading to cases of undocumented labor. ${ }^{5}$ Today, South Korea operates a selective and time-limited system for migrant labor that builds on these past programs. ${ }^{6}$ Controversially, holders of E-9 non-professional Employment visas are not permitted to live in Korea with family members and are only permitted a single, one-year 10-month extension of the original three-year visa (Korea Times, 2017). Despite these contentious stipulations, South Korea was home to 884,000 employed migrant workers as of May 2018, a 6\% rise year-on-year over 2017 (Statistics Korea, 2018a).

Marriage migration has also been actively encouraged by the state, most notably since the mid-2000s (Kim and Kilkey, 2018: 26). By 2012, there were almost 150,000 marriage migrants in South Korea, constituting about $8 \%$ of all migrants at the time (Cho, 2018: 102). In contrast with the incremental liberalization of rules covering migrant labor, regulations on marriage migration have grown somewhat stricter to combat abuses of both the rules and, on occasion, the migrant brides, and now include both language and income requirements (Cho, 2018: 116). ${ }^{7}$ Nevertheless, a total of 20,835 international marriages took place in 2017, and 123,546 people were legally resident in South Korea on F-6 visas, the category for those married to natives.

Finally, a total of 32,476 North Koreans had resettled in South Korea by the end of December 2018. ${ }^{8}$ Though Seoul does not generally encourage ordinary North Koreans to migrate from North to South, resettled North Korean migrants are structurally advantaged in South Korea. ${ }^{9}$ Defector-migrants receive comparatively comprehensive assistance, including the contingent right to protection and transfer to South Korea from abroad, financial and housing support to resettle, and various forms of free education (to university level) and employment training (Denney and Green, 2018). Resettled North Koreans are also the subject of innumerable cultural portrayals in South Korean media, many of them funded by government agencies seeking to encourage the integration of North Korean arrivals into South Korean society (Epstein and Green, 2019). 
South Korea's immigrant population will continue to grow. Migrant workers are projected to arrive in significant numbers, skilled workers are being targeted to fill high-skill positions, and marriage migrants are set to play a part in Seoul's attempts to ameliorate gender imbalances in farming regions for the foreseeable future (Korea Immigration Service, 2018, 2019). Currently, somewhere between 1000 and 2000 North Koreans flee their country each year, and most eventually arrive at South Korea's borders. ${ }^{10}$ How will native South Koreans think about the country's cohort of newcomers, and who, exactly, will they prefer? The comparative and Korea-specific literature guides our expectations.

\section{Theory overview: What explains attitudes towards immigrants among native South Koreans?}

What factors are held to explain natives' opinions toward immigrants? The comparative literature on immigration attitudes identifies several mutually constitutive explanations for public preferences. The three prominent theories explored here are labor market pressures, fiscal burden, and sociotropic concerns about the nation as a whole.

The first two of these focus on the political economy of immigration and posit that competition for scarce resources is the central motivating factor in the formation of views held by natives about immigrants. Under the hypothesis of labor market competition, natives would be expected to oppose immigration strongly in those cases where the incomers would be competing directly for jobs and wages (Cheve and Slaughter, 2001; Mayda, 2006). The tax burden hypothesis holds that opposition to immigration might be expected to increase where an influx of lowskilled immigrants is seen as likely to increase the cost of welfare provision and impose costs on natives in the form of higher taxes. It might also suggest that higher income natives would be less likely to support the entry of immigrants who have no plans to work (Facchini and Mayda, 2009; Hanson et al., 2007).

The sociotropic threat hypothesis, on the other hand, offers a relatively heterogenous socio-psychological explanation for attitudes to immigration (Hainmueller and Hopkins, 2014). It proposes that prospective immigrants are judged against the notion of a generalized, subjective threat to the national communities in which respondents live. This is not a threat to the respondent's own livelihood, as in the labor market competition hypothesis, or to their actual or prospective tax burden. Rather, it is a threat to the subjective 'imagined community', in the famous phrase of Anderson (1983; Valentino et al., 2017).

Hainmueller and Hopkins (2014) concur broadly with the sociotropic threat hypothesis, asserting in their conjoint research on the US that hypothetical immigrant applicants receive greater support from natives if it is the conclusion of the participant that the applicant is likely to make a robust economic contribution to the nation and adhere to a perceived and related set of cultural norms. This is in keeping with a portion of prior research using observational methods (Espenshade 
and Calhoun, 1993). Applicants with local language competence are also greatly preferred. $^{11}$

Naturally, though, there are challenges to these findings. The labor market competition hypothesis is supported by Scheve and Slaughter (2001), who conclude the low-skilled workers are more likely to support limiting immigration, because they think the US economy 'absorbs immigrant inflows at least partly by changing wages'. Citrin et al. (1997) suggest that personal economic circumstances do play a prominent role, and Hanson et al. note that 'high exposure to immigrant fiscal pressures' - the distorting tax and spend policies of government reduces native support for relatively freer immigration (Hanson et al., 2005).

More recent analysis has concluded that subjective perceptions of labor market threat and concerns over fiscal burden are - while present - not the best predictors of participant responses. Dustmann and Preston (2007) and Snidermann et al. (2004) find that an immigrant's country of origin matters, because of racial and cultural prejudice (especially for non-Hispanic whites in the United States), as well as cultural proximity (Espenshade and Calhoun, 1993), or some other form of social dominance (Newman et al., 2014). But it is a prospective immigrant's appreciable economic potential and willingness to adhere to a subjective set of national norms - language, laws and culture - that typically drive preferences. There is what Hainmueller and Hopkins (2014) call a strong 'unacknowledged consensus' across social classes in the US about what kind of immigrant is preferred. This finding was reproduced for the Canadian population, suggesting a broader American and Canadian consensus on immigration (Donnelly, 2017).

Unlike studies of North America in particular, the Korean case requires overt consideration of an ethnic dimension. The role of ethnicity in Korean nationalism is well established (see, e.g. Shin, 2006). Accordingly, South Korean attitudes towards immigrants are understood to be structured in part by co-ethnic affinity (Ha et al., 2016; Seol and Skrentny, 2009; Yoon, 2016). Jeong (2016) is among those to find evidence of greater ethnocentrism in the Korean case compared to Western states, even if ethnic affinity is conditional on co-ethnics' origins (cf. Lee and Chien, 2017; Lim and Seol, 2018).

However, other issues have been found to be equally, or more, salient than ethnicity. Campbell (2016) finds co-ethnic affinity giving way among college-age natives, replaced by status- and class-based attitudes towards national belonging. Seol and Skrentny (2009) find that there is a firmly established hierarchy among those countries that send co-ethnics to South Korea, suggesting that all co-ethnics are not treated as equals. Similarly, Ha et al. (2016) conclude that in-group favoritism' toward co-ethnics is, though present, by no means sufficient to explain South Korean views on immigration. They observe a preference for co-ethnics (North Korean defector-migrants) over what they call 'semi-coethnics' (Korean Chinese, who share some, but not all, cultural elements with native-born South Koreans), but respondents also display a clear preference for non-coethnics (Indonesians) over Korean Chinese, again confounding the hypothesis that a preference for fellow ethnic Koreans would predominate. 
Other research finds that generational differences and education levels are key drivers of support for immigration, suggesting that younger, better educated people are more open to immigration without regard for ethnicity than older and less well-educated cohorts (Hundt, 2016). Kong et al. (2010) find that the needs of the labor market and the urgency of ameliorating rural gender imbalances are just as salient to South Korea immigration and immigrant policies as co-ethnic sentiment. Harell et al. (2012) propose that origins-based discrimination might also be linked to security fears rather than ethnicity per se. Existing survey data for South Korea over the last decade show an increase in those who think crime rates rise as more immigrants enter the country. ${ }^{12}$ Accordingly, we expect to observe origins-based discrimination among countries more culturally distant from, or less developed than, South Korea, but we also expect to observe an interaction with respondents' professed national identity. Those who support a more multicultural or inclusive vision of South Korea would be less likely to discriminate based on an immigrant's country of origin compared to those who continue to see South Korea as an ethnically homogenous country.

In this paper, then, we consider whether an established, but inconclusive, preference for co-ethnics manifests in data alongside political-economic and/or sociopsychological explanations for immigration decisions and, if so, how? Given the inconclusive nature of past work on the subject, there is a need for further research into the Korean case. It is also a policy-relevant matter, given the rapidly rising number of immigrants arriving in South Korea and a bipartisan consensus on the need to admit many more in the coming years.

\section{Experimental design, data, and analysis}

This research slots into a contemporary trend of utilizing conjoint analysis, which allows for the isolation of key explanatory variables in attitudes toward immigrants. However, while the methodology is increasingly common, previous research of this type focuses almost exclusively on citizen attitudes in advanced industrial economies of North America (Hainmueller and Hopkins, 2014) and Western Europe (Sobolewska et al., 2017). Little has been said about developed democracies with more homogenous societies and shorter histories of hosting longterm immigrants in large numbers, a category that includes Japan, the Republic of Korea and several other Asian states. One significant contribution of this research is to expand the geographic and cultural frame of conjoint research into attitudes toward immigration and immigrants.

The choice-based conjoint offers several advantages over a standard, observational survey design. We identify two primary benefits. First, unlike typical surveys, a greater and more specific amount of information is provided to the respondent. Rather than simply ask respondents if they support more or less immigration, or how they feel about an immigrant group in Korea, the respondent is provided specific information about the 'immigrant'. Respondents are less likely to 'imagine' (cf. Blinder, 2013) who the immigrant is, instead responding 
to particular profiles. Including multiple attributes permits the respondent to make a more informed decision about their preference and permits the researcher to disaggregate variables that might otherwise be correlated (e.g. country of origin and skill-level of typical immigrant). The result is, in theory, less measurement error.

Second, the conjoint design mitigates the possibility of social desirability bias in answers about immigration (cf. An, 2015; Creighton et al., 2015). Since each profile contains varied immigrant characteristics, the respondent is free to discriminate while maintaining plausible deniability. Given more information and an unobtrusive way of expressing their opinion, respondents should feel freer to express their true preferences.

The conjoint design is not free from criticism. It can reasonably be accused of ignoring the role of government policy in shaping the playing field on which attitudes toward immigration are formed (Hammar, 2009). In addition to the discretionary power to set taxes and restrict access to welfare provision, the length of asylum processes and regulations surrounding naturalization are both in the gift of governments, and (in Switzerland) both have been found to substantively and negatively impact integration - and by extension, public opinion of immigrants (Hainmueller et al.,2015, 2016).

Nevertheless, the advantages of the conjoint design are established, and the point is not to reiterate them. Rather, it is to show how this design can be leveraged to better understand South Korean attitudes toward immigrants. The conjoint employed here asks respondents to consider two prospective immigrants to South Korea. Following a brief introduction, where the respondent is instructed to play the role of immigration official, they are asked to choose which of the two prospective immigrants they prefer. Based on seven immigrant attributes, profiles are randomly generated for each pair (each respondent evaluates six pairs in total). The attributes include the prospective immigrant's reason for application; country of origin; language capacity; profession; employment plans; gender; and ethnicity. The responses, our primary variable of interest, are taken as dichotomous outcome variables $(1=$ Immigrant Preferred, else 0$)$. As a robustness check, we also have respondents rate each respondent on the 7-point scale, with 7 meaning 'definitely admit' and 0 meaning 'absolutely do not admit'. Given that respondents are forced to choose between two profiles, it is possible that some respondents preferred one profile over the other but did not really care for either. Figure 1 shows an Englishlanguage example of what the respondents are shown.

Each attribute (or feature) contains various levels. For example, a prospective immigrant can be applying for entry to study, work short-term, claim asylum, or resettle. That same immigrant will be listed as coming from China, Japan, North Korea, Vietnam, the United States, or Yemen. They will either speak fluent Korean, no Korean, or have some in-between capacity. The ethnicity attribute also allows us to compare ethnic compatriots to non-ethnic compatriots from various countries. These attributes permit a wide range of theoretically possible combinations. ${ }^{13}$ 


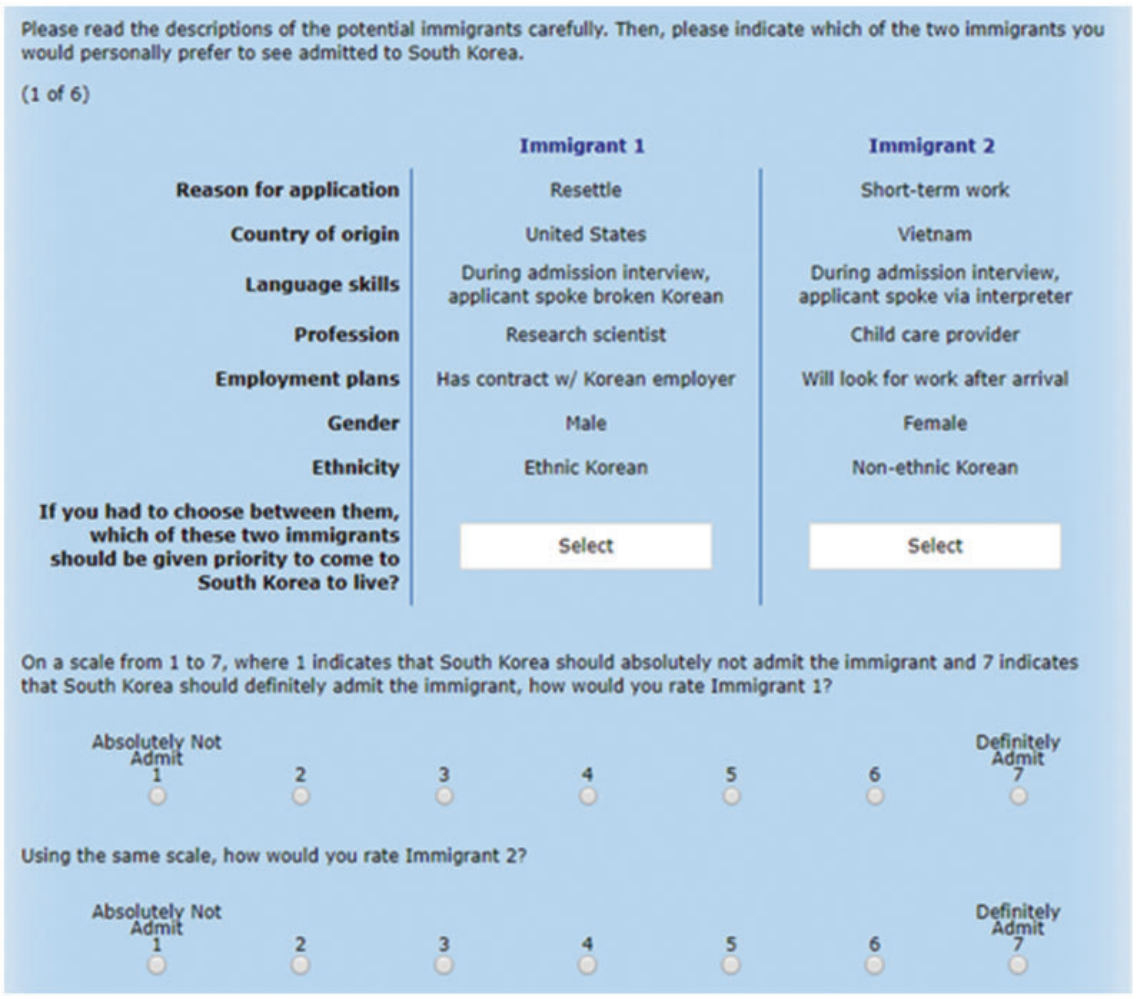

Figure I. The experimental design. An English-language approximation of the conjoint survey experiment, as read by respondents.

South Korea's immigrant population is not yet large or particularly diverse, but it is significantly more diverse than it was a decade ago, and it is growing. The attributes and levels were chosen deliberately, with the intention of creating immigrant profiles that contain plausible combinations of attribute levels.

Ideally, all possible immigrant profiles will be read as plausible. However, given our interests and objectives, the only way this could be accomplished would be to restrict the randomization of some attribute levels. For example, an immigrant from North Korea would, in the real world, almost always be an ethnic Korean and speak Korean fluently. There are some rare exceptions (there is a small contingent of ethnic Chinese citizens in North Korea) and some North Koreans may not speak Korean (fluently) because they defected from North Korea to China or elsewhere at an early age. But, by and large, North Koreans are understood as a linguistically and ethnically homogenous group and the migrants most similar to South Koreans. ${ }^{14}$

We decided against restricting the randomization of attribute values. Placing some randomization restrictions on a choice-based conjoint can make the 
Table I. Attributes and values for immigrant profiles in the conjoint experiment.

\begin{tabular}{|c|c|}
\hline Attributes & Values \\
\hline Reason for application & $\begin{array}{l}\text { Study } \\
\text { Short-term work } \\
\text { Claim asylum } \\
\text { Resettle }\end{array}$ \\
\hline Country of origin & $\begin{array}{l}\text { China } \\
\text { Japan } \\
\text { North Korea } \\
\text { Vietnam } \\
\text { United States } \\
\text { Yemen }\end{array}$ \\
\hline Language skills & $\begin{array}{l}\text { Speaks fluent Korean } \\
\text { Speaks broken Korean } \\
\text { Tries to speak Korean but unable } \\
\text { Speaks via interpreter }\end{array}$ \\
\hline Profession & $\begin{array}{l}\text { Agricultural worker } \\
\text { Child care provider } \\
\text { Nurse } \\
\text { Office worker } \\
\text { Teacher } \\
\text { Research scientist } \\
\text { Computer programmer } \\
\text { Doctor }\end{array}$ \\
\hline Employment plans & $\begin{array}{l}\text { Has contract w/ Korean employer } \\
\text { Does not have contract, but has done job interviews } \\
\text { Will look for work after arrival } \\
\text { No plans to look for work }\end{array}$ \\
\hline Gender & $\begin{array}{l}\text { Male } \\
\text { Female }\end{array}$ \\
\hline Ethnicity & $\begin{array}{l}\text { Ethnic Korean } \\
\text { Non-ethnic Korean }\end{array}$ \\
\hline
\end{tabular}

Note: The table shows what respondents read, translated into English.

experiment a better approximation of reality, but there are serious methodological concerns with doing so, because the regression estimation function typically used (average marginal components effects) assumes full randomization (Leeper et al., 2019). A small number of restrictions is not likely to harm statistical precision of estimates, but many restrictions can be devastating. ${ }^{15}$ Leeper et al. (2019) urge researchers using conjoint designs to avoid restricting randomization altogether. Accordingly, the conjoint employed here uses no restrictions on randomization. Table 1 lists all attribute and their values. 


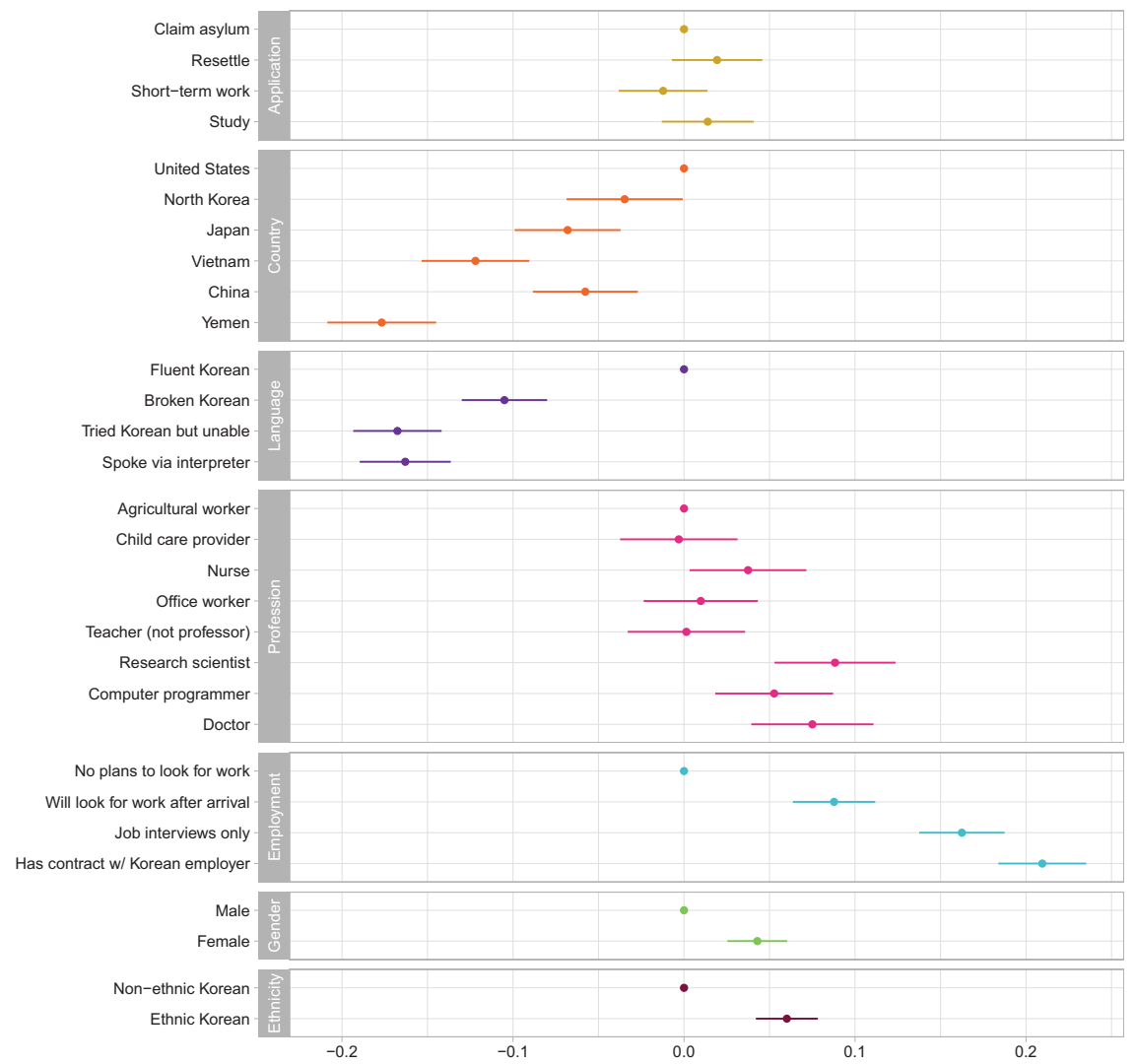

Figure 2. Effects of immigrant attributes on probability of being preferred for admission (x-axis). The average component marginal effects for the randomly generated attributes on the probability of being preferred for admission to South Korea. AMCEs for values of attributes shown with $95 \%$ confidence intervals and based on the baseline OLS model with standard clustered errors.

\section{Sample and analysis}

The sample in this study was drawn from Rakuten Insight's online panel of the South Korean adult population (18 years old and older). Following a pilot study, one single-wave survey of 1008 respondents completed the survey either on a computer or mobile device during February 2019. Sampling quotas, including age, region, and gender were used to ensure representativeness.

Following the statistical approach advised by Hainmueller et al. (2013) and commonly employed in conjoint analysis, we estimate average marginal component effects (AMCEs). The AMCE function estimates the marginal effects of attribute values, averaging over all other attributes. The means scores for each attribute level are estimated by regressing the dichotomous outcome variable from the force-choice option (Immigrant A/Immigrant B) against each categorical 
attribute variable. The estimated effects for each attribute level can be intuitively read as the change in probability of being admitted to South Korea. Each respondent rated six pairs each, yielding a total of 12,096 observations for the benchmark model $(1008 \times 6 \times 2)$. Since the observed choices are not independent across profiles, clustering the standard errors by respondent is necessary to obtain accurate variance estimates.

\section{Effects of immigrant attributes on probability of being admitted}

Figure 2 shows the baseline model, a linear probability model (ordinary least squares) with clustered standard errors. Each attribute has a specified reference category. The dots on the graph represent the point estimates and the bars show the $95 \%$ confidence intervals for the average marginal effects of each attribute level on the probability of being selected for admission. The full regression model in tabular form can be read in the Supplementary Information document (Table SI.2).

Overall, we find strong evidence that native South Koreans largely prioritize sociotropic and norms-based concerns in their immigration attitudes. Prospective immigrants who can, and are willing to, participate in society (e.g. speak Korean) and contribute meaningfully to the nation (have valuable skills and a proven willingness to work) are favored for immigration, largely regardless of other factors such as ethnicity. But South Koreans also condition their attitudes based on an immigrant's country of origin. Immigrants from culturally different or less developed countries are strongly discriminated against. Below we examine the baseline findings in detail, reviewing them by attribute, and then consider how the treatments interreact with respondents' background characteristics.

The baseline model shows that the reason people apply for entry into South Korea does not matter much. The positive effects for resettlement and study permits indicate some degree of approval for these reasons for entry, and shortterm work is least favored. But, in all cases, the effects relative to the baseline are minor and not statistically significant.

Conversely, a prospective immigrant's country of origin matters greatly. The United States (reference category) is most favored, as the relative effects of all other countries are negative. Immigrants hailing from North Korea are only slightly less preferred ( -3 percentage point [pp] effect on the probability of selection) and those from China and Japan are 6pp and 7pp less likely to be chosen. Those who originate from Vietnam (-12pp) and Yemen (-18pp) face strong discrimination.

Like an immigrant's country of origin, their Korean language capacity matters, too. We observe large negative effects for an applicant's inability to speak Korean, especially an inability to speak Korean fluently. Compared to the baseline (fluent Korean), those who speak broken Korean are $11 \mathrm{pp}$ less likely to be selected for admission, and there are no points given for effort. You either are or are not 
communicative in the language. The effects of trying but failing or using an interpreter are similar - a $16 \mathrm{pp}$ negative effect.

Regarding the prospective immigrants' professions, we see that coming from high-skill occupations is rewarded, although not as much as speaking Korean. Being a research scientist $(+9 p p)$, computer programmer $(+5 p p)$, nurse $(+4 p p)$, or doctor $(+8 \mathrm{pp})$ are more preferred than agricultural workers, whereas respondents reacted similarly to childcare providers, office workers, and teachers alike.

Employment plans are likewise notable as they show some of the biggest effects. Whether you have or are willing to work matters enormously. If a prospective immigrant has a contract with a Korean employer, they receive a 21 pp gain compared to someone who has no plans to work. Having done job interviews (a strong signal of employability or willingness to work) is likewise rewarded $(+16 \mathrm{pp})$. A willingness to work is not rewarded as much as having taken interviews or

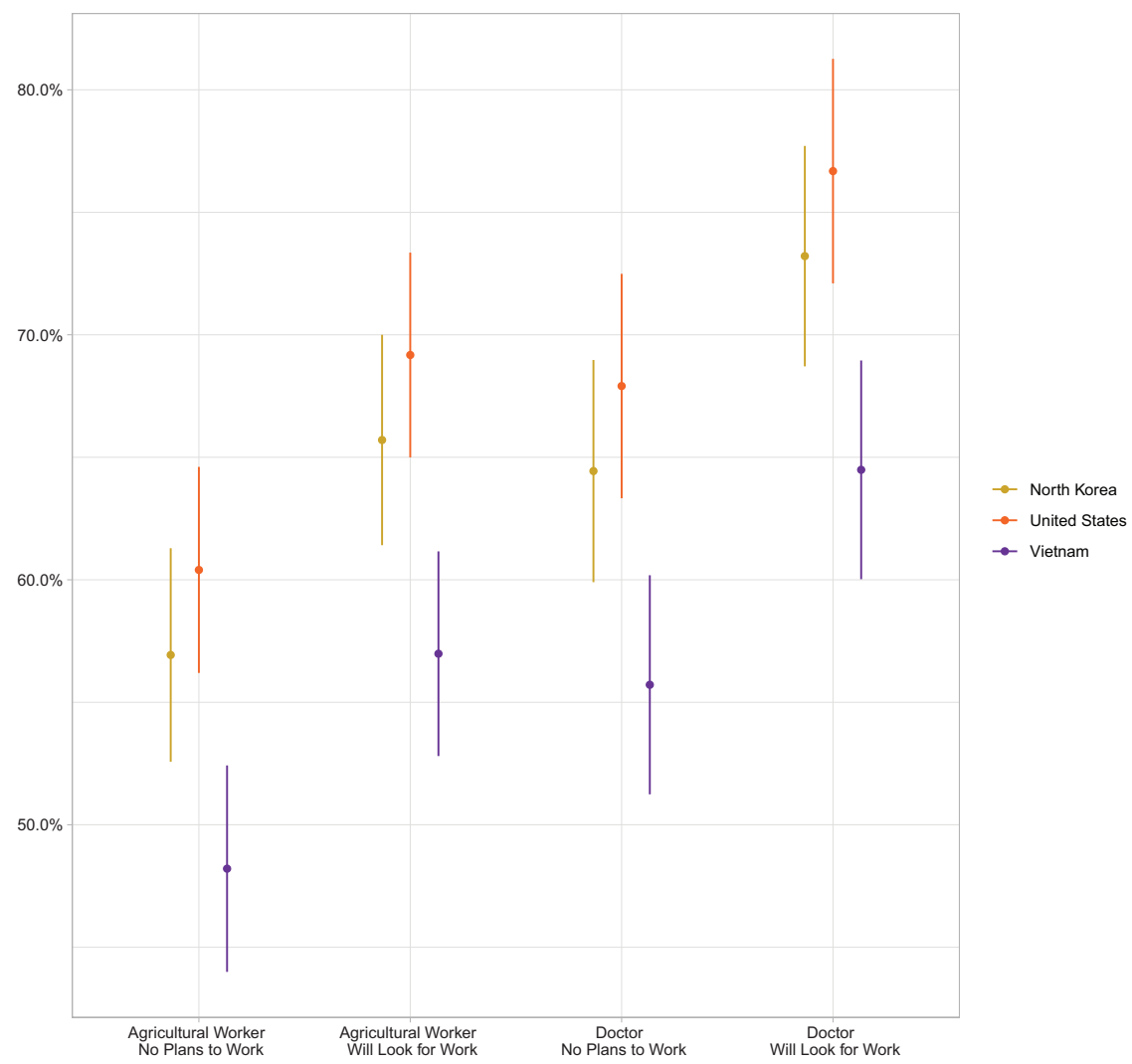

Figure 3. Estimated probability of being preferred for admission by selected profiles (y-axis). As specified, only occupation and employment plans vary. Estimates are based on the benchmark OLS model with clustered standards errors. The error bars show $95 \%$ confidence intervals. 
already having a job contract, but it does increase the probability of acceptance by 9pp.

Finally, the baseline findings show that gender and ethnicity matter, but only marginally. Females are 4pp more favored than males (read alternatively, male applicants are punished). There is also some evidence of a co-ethnic effect, with ethnic Korean immigrants 4pp more likely to be accepted, but this effect is relatively small when compared to the effects observed for country of origin, language capacity, and employment plans.

To better highlight the substantive implications of the immigration conjoint findings, the predicted probabilities of being preferred for entry are shown for selected immigrant profiles (Figure 3). The reason for application is held constant ('resettle'), as is language capacity ('fluent Korean'), gender ('female'), and ethnicity ('ethnic Korean'). We vary occupation (high skill/low skill), employment plans (will look for work/won't look for work), and country of origin (North Korea, United States, and Vietnam). The results underscore the importance of adhering to norms and expectations associated with working and the importance of national origin. Highly skilled immigrants (doctors) who have no plans to work are no more desired than low-skilled immigrants (agricultural workers).

\section{Interactions with respondent characteristics}

Findings from the benchmark model show that immigrants who can participate and function in society and indicate a willingness and ability to contribute economically are most preferred. There is evidence of origins-based discrimination and small gender and ethnic effects, but the main findings provide a strong confirmation of sociotropic theories of immigrant attitudes. This then leads us to the question of interactions between the immigrant attributes and respondents' background characteristics. For example, are well-educated South Koreans less likely to support similarly well positioned immigrants, as per the labor market hypothesis? Are South Koreans who have ethnocentric conceptions of national identity more like to discriminate based on country of origin, as theories of national identity suggest? In order to answer these questions, it is necessary to consider a number of moderating variables. In the section to follow, we reproduce the baseline OLS model by differing background characteristics of our respondents.

\section{Economic self-interest}

Following Hainmueller and Hopkins (2014: 540-541), we use education as an imperfect proxy for respondents' skill and status. We find some evidence of an interaction between respondents' education and profile of immigrant preferred (Figure 4). Notably, there is no skills-based discrimination. Those with some college or more are no more likely than those without college education to discriminate based on an immigrant's occupational background. In this regard, the labor market theory is not borne out. 


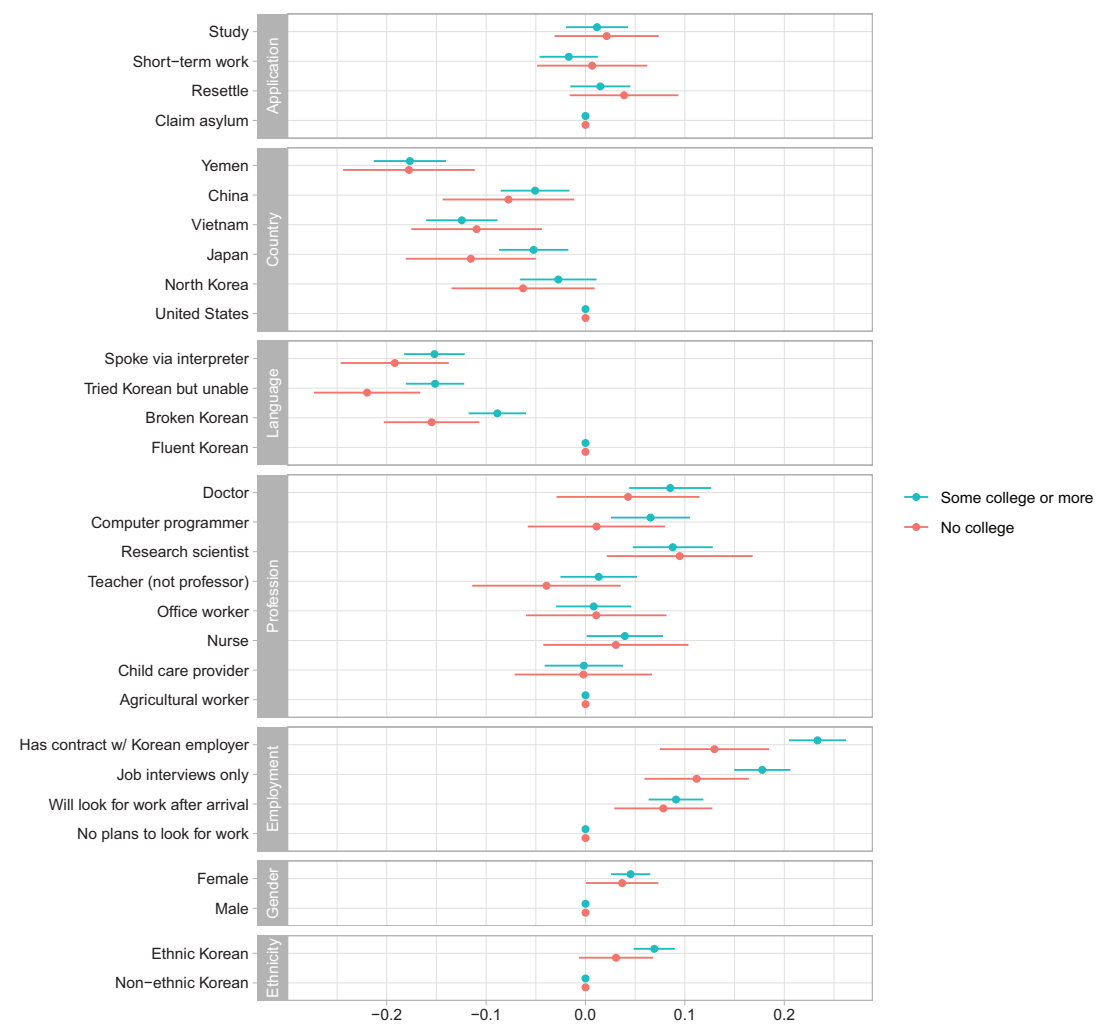

Figure 4. Effects of immigrant attributes on probability of being preferred for admission by education levels ( $x$-axis). The average component marginal effects for the randomly generated attributes on the probability of being preferred for admission to South Korea. AMCEs for values of attributes shown with $95 \%$ confidence intervals and based on the baseline OLS model with standard clustered errors.

There is, however, some evidence of sociographic or norms-based differences in opinions. Both college-educated respondents and those without college education favor immigrants who show a willingness and ability to work, but highly educated respondents place a greater amount of importance on the immigrant's employment plans. Specifically, prospective immigrants with work contracts are $23 \%$ more likely to be accepted among those with at least some college education, whereas the same immigrants are only 13pp more likely to be chosen among those with no college education. Similarly, immigrants who have taken job interviews are 18pp more likely to be accepted among the college educated, but only $11 \mathrm{pp}$ more likely among those without any college. Further, respondents with at least some college education do not punish prospective immigrants who struggle to speak Korean as much as those without college education. The noted differences are statistically significant at the $95 \%$ confidence level. 


\section{Ethnocentrism and national identity}

Given South Korea's history of ethnic nationalism and, until recently, ethnocultural homogeneity, it is reasonable to expect that who have more ethnocentric conceptions of nationality will discriminate against non-co-ethnics. They can also be expected to show greater prejudice against foreign nationals (save for perhaps North Koreans, who nominally belong to the same nation). The baseline replication models with an ethnocentrism moderator are based on a question about the respondents' preferred national identity - either a multicultural country of an ethnically homogenous one. Our empirical expectations are partly confirmed.

Figure 5 shows those professing low ethnocentrism - respondents who prefer a multicultural country over an ethnically homogenous one - discriminate less against all foreign nationals, including North Koreans (unsure/don't know

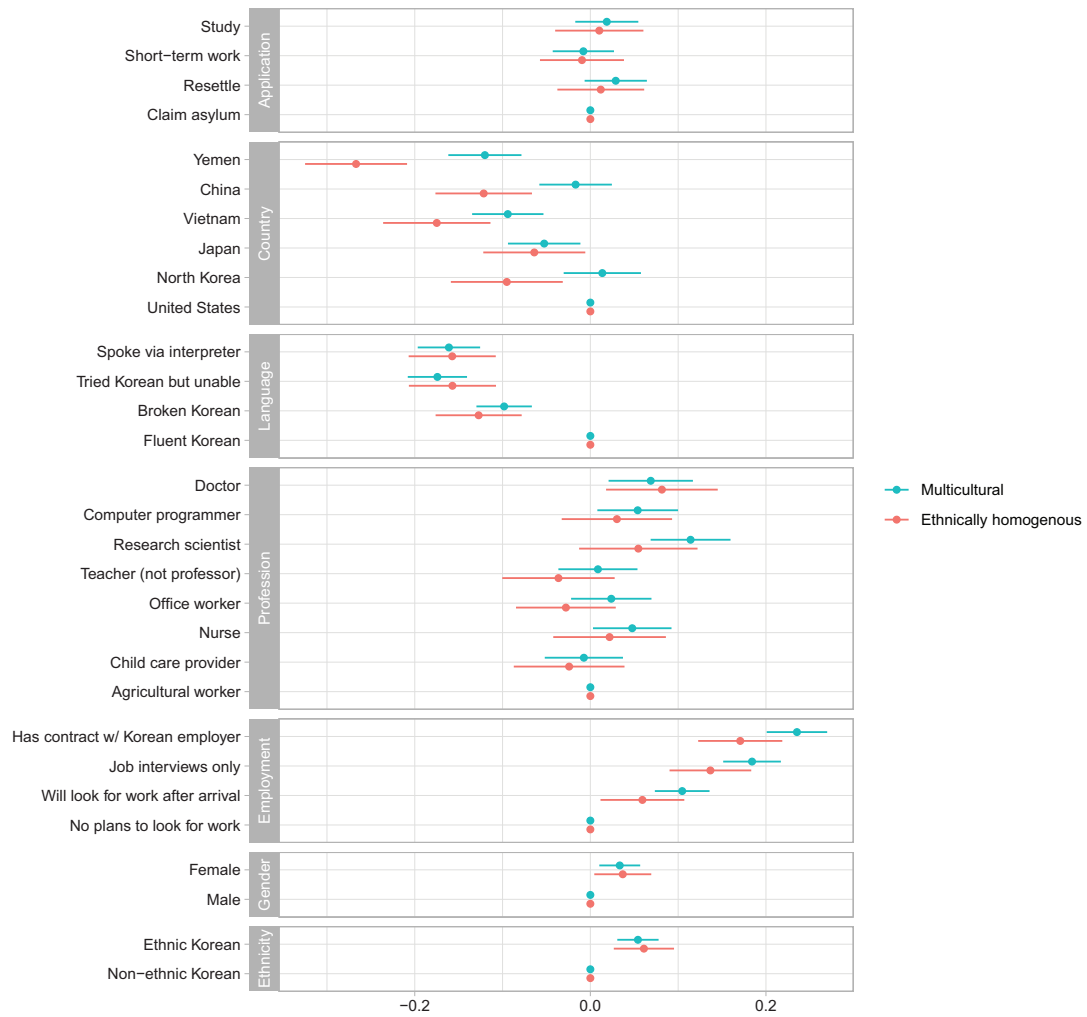

Figure 5. Effects of immigrant attributes on probability of being preferred for admission by national identification (x-axis). The average component marginal effects for the randomly generated attributes on the probability of being preferred for admission to South Korea. AMCEs for values of attributes shown with $95 \%$ confidence intervals and based on the baseline OLS model with standard clustered errors. 
excluded). The drop-off in origins-based discrimination between these two groups is most notable for those immigrants coming from China and Yemen. The difference is about 10 and 15 percentage points, respectively. Interestingly, those professing a multicultural preference also discriminate less against North Koreans. ${ }^{15}$ This is a counterintuitive, but instructive, finding, because it suggests that South Koreans may not extend their understanding of Korean ethnicity to include the Korean diaspora or co-ethnics born in third countries. In other words, in order to be truly 'South Korean' for those whom ethnicity is a salient component of national identity, one needs to have South Korean roots (cf. Campbell, 2016). ${ }^{16}$

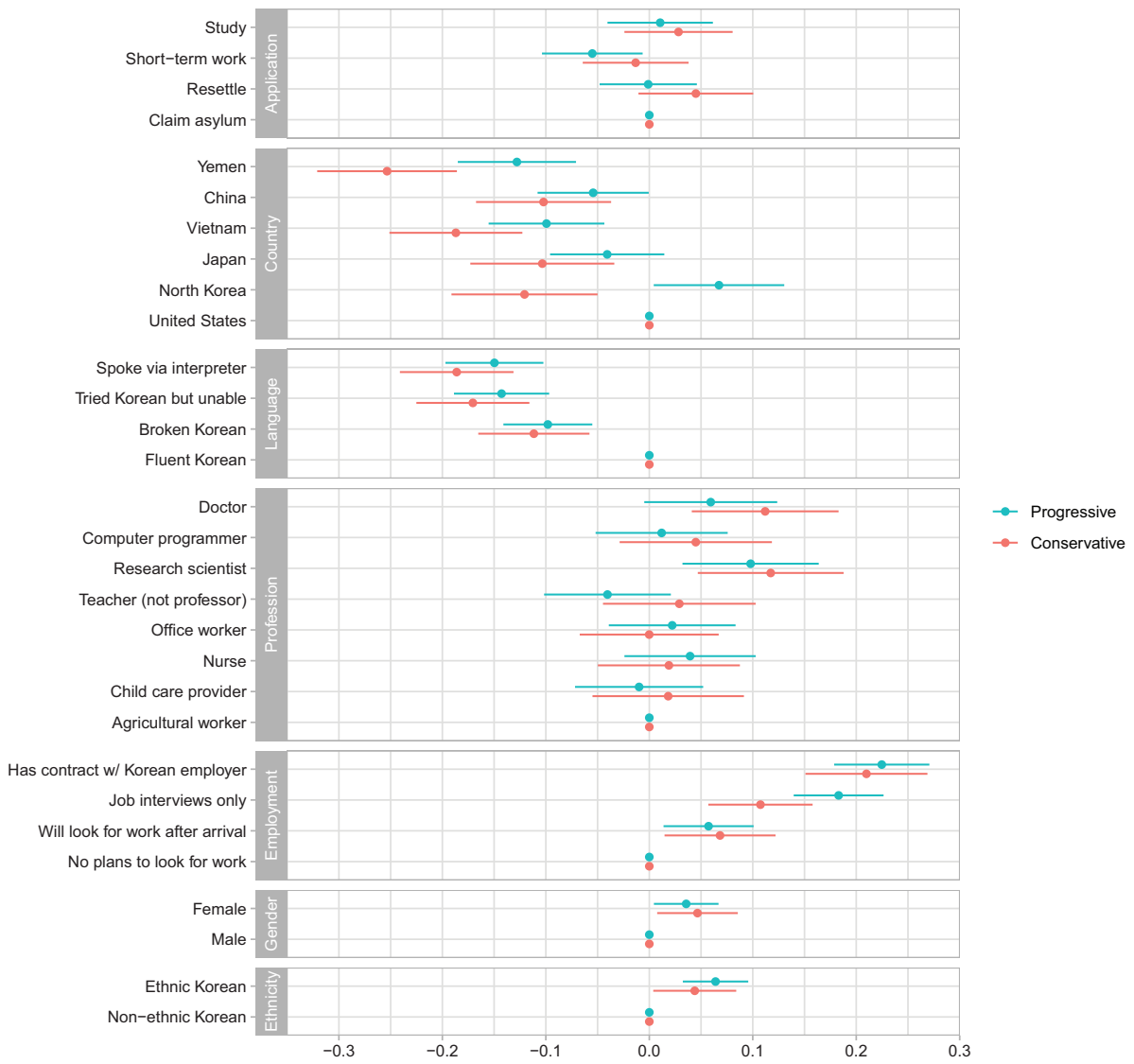

Figure 6. Effects of immigrant attributes on probability of being preferred for admission by political identification (x-axis). The average component marginal effects for the randomly generated attributes on the probability of being preferred for admission to South Korea. AMCEs for values of attributes shown with $95 \%$ confidence intervals and based on the baseline OLS model with standard clustered errors. 
Regardless of the preference for type of country (multicultural/homogenous), ethnic Koreans are slightly preferred over non-ethnic Koreans, when averaging the co-ethnic effect over all others. It is reasonable to expect the co-ethnic effect to disappear for respondents who prefer a multicultural South Korea, but it is not contradictory to have a multicultural preference and prefer co-ethnics. The Korean diaspora hails from various places in the world, after all, bringing with them different cultural practices and beliefs. This finding underscores an important point - that multiculturalism is context-specific. Multiculturalism in a country like Canada (cf. Hansen, 2017) does not mean the same thing as it does in Korea.

\section{Ideology}

Lastly, we consider the possible interaction effects with respondents' political identification. The idea that political identification intersects with immigration attitudes is not unique to South Korea, but it is particularly apt in this case. Given the differences in South Korea's social and political cleavages (Kim et al., 2008), it is unclear whether progressives in South Korea should be expected to show greater openness towards immigrants. There are, however, clear differences in conceptions of national identity by political identification. Progressives are expected to favor co-ethnics and hold North Koreans in higher regard than conservatives. Conservatives, by contrast, are expected to be more skeptical of North Koreans, will hold the US (as a country of origin) in higher regard, and may not favor coethnics less than progressives. ${ }^{17}$

The benchmark model replications in Figure 6 mainly confirm our expectations. Progressives show less prejudice towards countries less developed than, or different from, the US. Moreover, they prefer immigrants from North Koreans over all others. This finding speaks to the difference in conception of nation, where coethnics (from North Korea) are seen as integral members of the nation for those identifying as progressive, but markedly less so for conservatives. The differences in opinion also show a weaker, origins-based discrimination effect among conservatives, a finding in line with expectations.

\section{Discussion and conclusion}

Given that existing scholarship tends to foreground ethnicity and ethnonationalism among the peoples of the Korean peninsula, it is an important finding that the main concerns of South Koreans where immigration is concerned are plainly similar to those that emerge from analogous research from North America and Western Europe. It seems entirely appropriate to extend the 'unacknowledged consensus' of prior research regarding immigration attitudes to South Korea. Broad sociotropic concerns related to immigrants' Korean language capacity and employment plans are the most important attributes across social groups in South Korea. A prospective immigrant's appreciable economic potential and 
willingness to adhere to a subjective set of national norms - language, laws and culture - are clearly the most important factors weighing on respondents to the conjoint experiment.

Where we see differences and variation is in the country of origin-based discrimination. Different from North Americans but more similar to some Western Europeans, South Koreans care about the origins of immigrants. This is an interesting and complicated finding, but it is not completely unexpected. Countries from which immigrants hail are associated with varying levels of status, development, and cultural similarity or distance. Seol and Skrentny (2009) find that, among ethnic return migrants, those from more developed countries (e.g. the United States) are awarded better legal and social standing than those from less developed countries (e.g. China). Campbell (2016) shows evidence of status-based discrimination replacing co-ethnic solidarity. The fact that, overall, immigrants from the United States are slightly more preferred over co-ethnic migrants from North Korea is instructive and supports both previous findings and our interpretation of the data.

Notably, despite North Korea's status as an underdeveloped country, those from this country are still well received. This is likely due to cultural similarities, plus the nature of the relationship between the citizens of North and South Korea - nominally, one nation divided. Also, South Koreans are subject to a range of mostly positive cultural and educational portrayals of North Korean defectormigrants, and as a result are unusually knowledgeable about North Korea - its political system, widespread repression, famine and food insecurity, and so on. Comparison with the example of a geographically remote nation in this study, Yemen, is instructive. The discrimination we observed against Yeminis is noteworthy but, again, not entirely unexpected; those both culturally dissimilar and from less developed places are clearly not desired.

Modest interactions with respondents' characteristics were found, some of which are policy-relevant. First, highly educated South Koreans are slightly more concerned about prospective immigrants' employments plans than are the less well educated, but, importantly, the lower educated do not indicate any evidence of economic anxiety about immigrants with lower skill sets. This reinforces the point that views are unrelated to labor market concerns or fiscal policy, a finding that is in contrast with the apparent anxiety felt by South Korea's immigration service (Korea Immigration Service, 2019). Second, those with high ethnocentrism (i.e. those who support an ethnically homogenous nation) discriminate more based on country of origin overall, especially for those from a culturally different country (e.g. Yemen). Interestingly, self-identifying progressives prefer those from North Korea over the United States - the only instance in which a country of origin other than the US was preferred. This is in line with the national identity differences between progressives and conservatives (de Vries et al., 2013).

We consider a number of additional background characteristics in the Supplementary Information (SI), including age, gender, income, geography, and generational effects. In no instance do results differ significantly from the 
benchmark model. The SI also presents several robustness checks. For the first robustness check, we consider whether answers based on 7-point scales for each immigrant result in opinions significantly different from the forced-choice answers used for the benchmark AMCE model. Following Hainmueller and Hopkins (2014), we code ratings-based answers as 1 if the score is above the midpoint, otherwise 0 . We then replicate the benchmark model using this new dichotomous outcome variable (Figure SI.6). The results are substantively identical to the original model based on the forced-choice answers.

Second, we consider whether respondents satisfice or change their answers as they view more immigrant pairs (Figure SI.7). We find no evidence of satisficing or other patterns indicating a chance in respondent answers as they view more profiles. Third, we explore potential social desirability biases by examining those who self-monitor (i.e. those more likely to be affected by social desirability biases). We found no significant differences in opinion between those who self-monitor and those who do not (Figure SI.8).

Fourth, we examine exposure to profiles consisting of unlikely attribute combinations (e.g. a North Korean who is not ethnically Korean) and determine whether these influence respondents to answer differently, possibly indicating that they are not taking the experiment seriously. Figure SI.10 shows that responses do not significantly differ between those exposed to several atypical profiles and those not exposed to any, or only a few, atypical profiles.

Fifth, we use a content analysis method to analyze 1008 open-text answers provided by respondents after viewing the third pair of prospective immigrant profiles. The question asked respondents to tell us why they selected the profile they did. Table SI.3 shows the content of the answers largely aligns with the theory-based explanations of the conjoint findings. Sociotropic concerns and, to a lesser extent, ethnocultural and origin-based themes emerge, confirming the main findings derived from the conjoint.

Overall, we see the main guiding question underpinning the findings is not how immigrants affect the individual, but how they affect the nation as a whole. It is no small challenge to the notion of a country defined by a strong and necessarily exclusive ethnic nationalism that sociotropic concerns - mainly, functional (language) and contribution-based (employment) concerns - far outweigh those of ethnic solidarity. But, to regular and recent visitors to South Korea, the findings may seem predictable. South Korea is an increasingly pluralistic, democratic society with a vibrant public sphere. Ethnic exclusivism and ethnocultural ideas of national membership and belonging are at odds with these developments.

\section{Acknowledgements}

The researchers would like to acknowledge Michael Donnelly, Lior Sheffer, Joseph Wong, and Zain Asaf for their helpful feedback in the research design stage. We received additional feedback on an initial draft from fellow panel members and participants at the 2019 Midwest Political Science Association Conference. Remco Breuker, Michael Meffert, and 
Elmer Veldkamp provided additional feedback on the research findings at an event at Leiden University, for which we are grateful.

\section{Declaration of conflicting interests}

The author(s) declared no potential conflicts of interest with respect to the research, authorship, and/or publication of this article.

\section{Funding}

The author(s) disclosed receipt of the following financial support for the research, authorship, and/or publication of this article: The authors received generous financial support from the UniKorea Foundation's 2018 Grant Program.

\section{ORCID iD}

Steven Denney (D) https://orcid.org/0000-0002-6542-1055

\section{Supplemental material}

Supplemental material for this article is available online.

\section{Notes}

1. See Korea Immigration Service. Available at: www.index.go.kr/potal/main/Each DtlPageDetail.do?idx_cd $=2756$ (accessed 2 April 2019) and Korean Statistical Information Service. Available at: http://kosis.kr/statisticsList/statisticsListIndex.do? menuId = M_01_01\&vwcd = MT_ZTITLE\&parmTabId = M_01_01\&statId = 1976077\&themaId = A\#SelectStatsBoxDiv (accessed 10 April 2019).

2. Pew Research Center documents migrants by country at: www.pewresearch.org/global/ interactives/international-migrants-by-country/ (accessed 18 November 2019).

3. These three main categories of immigrant have been augmented to a limited extent by a fourth: refugees. Following the enactment of Asia's first refugee law in 2013, Korea has seen a significant increase in the number of applicants for refugee status: 5069 applications in total between 1994 (following South Korea's accession in 1992 to the UN Convention Relating to the Status of Refugees) and 2012 became 5711 in 2015, 7541 in 2016, and 9942 in 2017. However, the contribution of this category of migrant to overall migrant numbers remains trivial, as there has been no concomitant increase in the number of applicants being granted refugee status. Marking the fifth anniversary of the enactment of the Refugee Law in 2018, it was widely noted locally that just $4.1 \%$ of all applicants - just 839 out of a total of 40,470 - had been accepted (Reuters, 2018).

4. World Bank. Available at: https://data.worldbank.org/indicator/NY.GDP.PCAP.CD? locations $=$ KR (accessed 10 April 2019).

5. The EPS system allows employers who can evidence an inability to hire local labor to legally employ foreign workers. Notably, the introduction of the EPS was accompanied by South Korea's first and, so far, only instance of the mass regularization of undocumented migrant labor (Lee and Skrentny, 2015: 308). 
6. This has resulted in what has been rather pejoratively called 'managed multiculturalism' (Lee and Skrentny, 2015: 322). Notably, it is not possible for a migrant laborer to bring family to South Korea,

7. The system encourages co-ethnic immigration (from some places more eagerly than others) and goes quite a long way to accommodate the long-term settlement of multicultural families, but moves more slowly - though it nevertheless moves - to codify and enhance the rights of migrant workers. It is pointed out that the immigrant population of South Korea is not 'diverse' at all, given that most incoming migrants come from a handful of Asian countries (Kong et al., 2010).

8. Ministry of Unification, Available at: www.unikorea.go.kr/unikorea/business/statistics/ (accessed 22 November 2019). Comprehensive statistics for the period 1948-1998 are unavailable. The number cited here does not reflect deaths or onward migration.

9. Defector-migrants do not necessarily feel advantaged, however, since the generosity of the state is in contrast with the discriminations many feel in society (Sohn, 2013).

10. Ministry of Unification. Available at: www.unikorea.go.kr/unikorea/business/statistics/ (accessed 22 November 2019).

11. It is true that respondents who have revealed a relatively more ethnocentric bias through prior baseline questions also penalize applicants from disfavored ethnic backgrounds, though these effects are limited.

12. Data from Korean General Social Survey (KGSS) in 2003 find that $33 \%$ of respondents agree that immigrants increase crime rates. The same question asked in the East Asia Institute's 2015 national identity survey (used in Lee and Yun (2016)) finds that 52\% agree. Fear of those culturally different was on display during a national debate about whether to accept Yemini asylum-seekers who had landed on Jeju Island (New York Times, 2018).

13. The order of the attributes shown to each respondent is fixed. The order shown is the same across respondents.

14. We were particularly interested in how those hailing from North Korea, people viewed by many as part of a greater Korean nation whose rightful government resides in South Korea, are thought of compared to those from elsewhere. North Koreas are automatically granted South Korean citizenship once they pass through the immediate postmigration resettlement process (which includes a security check), as per the South Korean constitution. We acknowledge this legal fact but given our interest in coethnicity effects opted to grant hypothetical power to the respondent to refuse entry to those from North Korea.

15. This project ran a pilot of the conjoint design with restrictions for profiles including prospective immigrants from North Korea. Those from North Korea could only claim asylum, speak fluent Korea, be an ethnic Korean, and either look for work after arrival or have no plans for work. The damage to statistical precision of the estimates for North Korea as country of origin was significant. Without restrictions, the number of implausible profiles is estimated to be approximately $6 \%$ of all profiles. See the Supplementary Information for more on potential effects of implausible profiles.

16. As a robustness check, we also considered an alternative measure for ethnocentrism: whether having Korean ethnicity is important for being 'truly South Korean'. Between those who agree it is important those who do not, the findings are effectively identical to those who prefer a multicultural country to an ethnically homogenous one. 
17. Henry Em (2013) outlines the historical origins of this predisposition. For data on contemporary attitudes, see Kim, Lee, and Kang (2015). Progressives identify more strongly with a sense of pan-Korean nationhood (which would necessarily include North Korea) than do conservatives or moderates. See also: chapter two in Lee and Yun (2016).

\section{References}

An BP (2015) The role of social desirability bias and racial/ethnic composition on the relation between education and attitude toward immigration restrictionism. The Social Science Journal 52: 459-467.

Anderson B (1983) Imagined Communities: Reflections on the Origin and Spread of Nationalism. London: Verso.

Blinder S (2013) Imagined immigration: The impact of different meanings of 'immigrants' in public opinion and policy debates in Britain. Political Studies 63(1): 80-100.

Boyon N (2018) The Inclusiveness of Nationalities: A Global Advisor Survey. Report, Ipsos Public Affairs.

Campbell E (2016) South Korea's New Nationalism: The End of 'One Korea'? Boulder, CO: Lynne Rienner.

Cheve KF and Slaughter MJ (2001) Labor market competition and individual preferences over immigration policy. Review of Economics and Statistics 83(1): 133-145.

Cho SY (2018) A bride deficit and marriage migration in South Korea. International Migration 56(6): 100-119.

Choi W (2016) The transformation of the Korean Chinese community: The case of the age of migration in China. Journal of Contemporary Korean Studies 3(1-2): 245-264.

Citrin J, Green DP, Muste C, et al. (1997) Public opinion toward immigration reform: The role of economic motivations. The Journal of Politics 59(3): 858-881.

Creighton M, Amaney J and Malancu N (2015) Has opposition to immigration increased in the united states after the economic crisis? An experimental approach. International Migration Review 49(3): 727-756.

Denney S and Green C (2018) Unification in action? The national identity of North Korean defector-migrants: Insights and implications. KEI Academic Paper Series, October 1. Available at: www.keia.org/sites/default/files/publications/kei_aps_green_ denney_180928.pdf (accessed 10 March 2020).

de Vries CE, Hakhverdian A and Lancee B (2013) The dynamics of voters' left/right identification: The role of economic and cultural attitudes. Political Science Research and Methods 1(2): 223-238.

Donnelly M (2017) Canadian Exceptionalism: Are We Good or Are We Lucky? Montreal, Canada: McGill Institute for the Study of Canada (MISC).

Draudt D (2019) Multiculturalism as state developmental policy in Global Korea. In: Gregg A. Brazinsky (ed) Korea and the World: New Frontiers in Korean Studies. New York: Lexington, pp. 157-178.

Dustmann C and Preston I (2007) Racial and economic factors in attitudes to immigration. BE Journal of Economic Analysis \& Policy 7(1): 1-39.

Henry Em HH (2013) The Great Enterprise: Sovereignty and Historiography in Modern Korea. Durham: Duke University Press.

Epstein S and Green C (2019) Revealing voices? North Korean Males and the South Korean Mediascape. In: Youna Kim (ed.) South Korean Popular Culture and North Korea. London: Routledge, pp. 176-188. 
Espenshade TJ and Calhoun CA (1993) An analysis of public opinion toward undocumented immigration. Population Research and Policy Review 12(3): 189-224.

Facchini G and Mayda AM (2009) Does the welfare state affect individual attitudes toward immigrants? Evidence across countries. Review of Economics and Statistics 91(2): 295-314.

Ha SE, Cho SJ and Kang JH (2016) Group cues and public opposition to immigration: Evidence from a survey experiment in South Korea. Journal of Ethnic and Migration Studies 42(1): 136-149.

Hainmueller J, Hangartner D and Lawrence D (2016) When lives are put on hold: Lengthy asylum processes decrease employment among refugees. Science Advances 2(8): e1600432.

Hainmueller J, Hangartner D and Pietrantuono G (2015) Naturalization fosters the longterm political integration of immigrants. Proceedings of the National Academy of Sciences of the United States of America 112(41): 12651-12656.

Hainmueller J and Hopkins DJ (2014) Public attitudes toward immigration. Annual Review of Political Science 17(1): 225-249.

Hainmueller J, Hopkins DJ and Yamamoto T (2013) Causal inference in conjoint analysis: Understanding multidimensional choices via state preferences experiments. Political Analysis 22(1): 1-30.

Hammar T (2009) European Immigration Policy: A Comparative Study. New York, NY: Cambridge UP.

Hansen R (2017) Why both the left and the right are wrong: Immigration and multiculturalism in Canada. PS: Political Science \& Politics 50(3): 712-716.

Hanson GH, Scheve KF and Slaughter M (2005) Public Finance and Individual Preferences over Globalization Strategies. National Bureau of Economic Research Working Paper no. 11028.

Hanson GH, Scheve K and Slaughter MJ (2007) Public finance and individual preferences over globalization strategies. Economics \& Politics 19(1): 1-33.

Harell A, Soroka S, Iyengar S, et al. (2012) The impact of economic and cultural cues on support for immigration in Canada and the United States. Canadian Journal of Political Science 45(3): 499-530.

Hundt D (2016) Public opinion, social cohesion, and the politics of immigration in South Korea. Contemporary Politics 22(4): 487-504.

Jeong HO (2016) A new comparison of the East and West: National identity and attitudes toward immigration. Asian and Pacific Migration Journal 25(2): 206-219.

Johnson C and Rodger S (2015) Did perception of the economy affect attitudes to immigration at the 2010 British General Election? Social Science Quarterly 96(5): $1214-1225$.

Kim AE (2009) Global migration and South Korea: Foreign workers, foreign brides and the making of a multicultural society. Ethnic and Racial Studies 32(1): 70-92.

Kim GC and Kilkey M (2018) Marriage migration policy in South Korea: Social investment beyond the nation state. International Migration 56(1): 23-38.

Kim HM, Choi JY and Cho J (2008) Changing cleavage structure in new democracies: An empirical analysis of political cleavages in Korea. Electoral Studies 27(1): 136-150.

Kim JY, Lee JJ and Kang CK (2015) Measuring A Giant: South Korean Perceptions of the United States. Report, Asian Institute for Policy Studies Public Opinion Studies Program. 
Kim NK (2014) Multicultural challenges in Korea: The current stage and a prospect. International Migration 52(2): 100-121.

Kim SW (2003) Korean General Social Survey (KGSS). Ann Arbor, MI: Inter-university Consortium for Political and Social Research [distributor], 2015-06-16.

Kim WB (2004) Migration of foreign workers into South Korea: From periphery to semiperiphery in the global labor market. Asian Survey 44(2): 316-335.

Kong DS, Yoon KW and Yu SY (2010) The social dimensions of immigration in Korea. Journal of Contemporary Asia 40(2): 252-274.

Korea Immigration Service (2018) The 3rd Master Plan for Immigration Policy. Policy document, June. Available at: http://bit.ly/2rhZPr8 (accessed 22 November 2019).

Korea Immigration Service (2019) Skilled worker quota to expand, with measures taken to welcome more global talent in areas not affecting Korean workers' jobs. Press release, September 27. Available at: www.immigration.go.kr/immigration_eng/1832/subview.do? enc $=$ Zm5jdDF8QEB8JTJGYmJzJTJGaW1taWdyYXRpb25fZW5nJTJGMjI5JTJGNT EyNTg0JTJGYXJ0Y2xWaWV3LmRvJTNG (accessed 22 November 2019).

Korea Times (2017) Korea moves to limit E-9 visa extensions for foreign workers. 3 August. Available at: www.koreatimes.co.kr/www/nation/2017/08/177_234116.html (accessed 10 March 2020).

Lee JJG and Skrentny JD (2015) Korean multiculturalism in comparative perspective. In: John Lie (ed) Multiethnic Korea? Multiculturalism, Migration, and Peoplehood Diversity in Contemporary South Korea. Berkeley, CA: Institute of East Asian Studies, University of California, pp. 301-330.

Lee NY and Yun IJ (eds) (2016) 한국인 의 정체성. 변화 와 연속, 2005-2015 [South Korean Identity: Change And Continuity, 2005-2015]. Seoul: East Asia Institute.

Lee S and Chien YC (2017) The making of 'skilled' overseas Koreans: Transformation of visa policies for co-ethnic migrants in South Korea. Journal of Ethnic and Migration Studies 43(13): 2193-2210.

Leeper TJ, Hobolt SB and Tilley J (2019) Measuring subgroup preferences in conjoint experiments. Political Analysis. Available at: https://doi.org/10.1017/pan.2019.30 (accessed 23 March 2020).

Lim T (2009) Who is Korean? Migration, immigration, and the challenge of multiculturalism in homogenous societies. The Asia-Pacific Journal 7: (30. 1). Available at: https:// apjjf.org/-Timothy-Lim/3192/article.html (accessed 10 March 2020)

Lim T and Seol DH (2018) Explaining South Korea's diaspora engagement policies. Journal of Asian Sociology 47(4): 633-662.

Mayda AM (2006) Who is against immigrants? A cross-country investigation of individual attitudes towards immigrants. Review of Economics and Statistics 88(3): 510-530.

Newman BJ, Hartman TK and Taber CS (2014) Social dominance and the cultural politics of immigration. Political Psychology 35: 165-186.

New York Times (2018) Just 2 of More Than 480 Yemenis Receive Refugee Status in South Korea. 14 December. Available at: www.nytimes.com/2018/12/14/world/asia/yemensouth-korea-refugees.html (accessed 10 March 2020).

Oh DC and Oh C (2016) 'Until You Are Able': South Korean multiculturalism and hierarchy in my little hero. Communication, Culture and Critique 9(2): 250-265.

Park YB (1994) The turning point in international migration and economic development in Korea. Asian and Pacific Migration Journal 3(1): 149-174. 
Poushter J, Feteerfolf J and Tamir C (2019) A changing world: Global views on diversity, gender equality, family life and the importance of religion. Report, Pew Center Research. Available at: www.pewresearch.org/global/wp-content/uploads/sites/2/2019/ 04/Pew-Research-Center_Global-Views-of-Cultural-Change_2019-04-22.pdf (accessed 11 October 2019).

Reuters (2018) South Korea to tighten asylum laws as hundreds of Yemenis arrive. 29 June. Available at: https://uk.reuters.com/article/uk-southkorea-yemen-refugees/south-koreato-tighten-asylum-laws-as-hundreds-of-yemenis-arrive-idUKKBN1JP0RQ (accessed 21 March 2020).

Seol DH and Skrentny JD (2009) Ethnic return migration and hierarchical nationhood: Korean Chinese foreign workers in South Korea. Ethnicities 9(2): 147-174.

Shin GW (2006) Ethnic Nationalism in Korea: Genealogy, Politics, and Legacy. Stanford, CA: Stanford University Press.

Snidermann PM, Hagendoorn L and Prior M (2004) Predisposing factors and situational triggers: Exclusionary reactions to immigrant minorities. American Political Science Review 98(1): 35-49.

Sobolewska M, Galandini S and Lessard-Phillips L (2017) The public view of immigrant integration: Multidimensional and consensual. Evidence from survey experiments in the UK and the Netherlands. Journal of Ethnic and Migration Studies 43(1): 58-79.

Sohn SH (2013) Living in a consumer society: Adaptation experiences of North Korean youth defectors in South Korea. Asian and Pacific Migration Journal 22(1): 109-131.

Statistics Korea (2018) Final Results of Birth Statistics in 2017. Press release, 22 August. Available at: http://kostat.go.kr/portal/eng/pressReleases/8/10/index.board?bmode $=$ read\&bSeq $=\& a S e q=370670 \&$ pageNo $=1 \&$ rowNum $=10 \&$ navCount $=10 \&$ currPg $=$ $\&$ searchInfo $=\&$ sTarget $=$ title\&sTxt $=($ accessed 12 March 2020).

Statistics Korea (2018a) Results of the 2018 Immigrant Sojourn and Employment Survey [2018 년 이민자 체류실태 및 고용조사 결과]. Press release, December 19. Available at: http://kostat.go.kr/portal/korea/kor_nw/1/1/index.board?bmode $=$ read\&aSeq $=372125$ (accessed 22 November 2019).

Valentino NA, et al. (2017) Economic and cultural drivers of immigrant support worldwide. British Journal of Political Science 1-26.

Yoon IJ (2016) Changes in Koreans' perceptions of multiculturalism and multicultural minorities: From paternalism to indifference? [한국인의 다문화와 다문화 소수자에 대 한 인식 변화: 온정주의에서 냉담주의로?]. In: Nae-young Lee and In-Jin Yoon (eds) South Korean Identity: Change and Continuity, 2005 2015 [한국인의 정체성: 변화와 연 속, 2005 2015]. Seoul: East Asia Institute, pp. 71-99. 